\title{
Marine micronutrient vectors: seabirds, marine mammals and fishes egest high concentrations of bioactive metals in the subantarctic island ecosystem
}

\author{
S. R. Wing ${ }^{1, *}$, L. C. Wing ${ }^{1}$, O. A. Shatova ${ }^{1}$, R. Van Hale ${ }^{2}$ \\ ${ }^{1}$ Department of Marine Science and ${ }^{2}$ Department of Chemistry, University of Otago, PO Box 56, Dunedin 9054, New Zealand
}

\begin{abstract}
We investigated concentrations of bioactive metals ( $\mathrm{Mn}, \mathrm{Fe}, \mathrm{Co}, \mathrm{Ni}, \mathrm{Cu}, \mathrm{Zn}, \mathrm{As}, \mathrm{Cd}$ ) in organic matter source pools: suspended particulate organic matter and macroalgae, and macrozooplankton from the vicinity of the Snares Islands, situated adjacent to the Subtropical Frontal Zone south of New Zealand. Further we sampled egested material from 6 coastal fishes, 8 seabirds and 2 pinniped species with rookeries on the islands. Analysis of $\delta^{15} \mathrm{~N}$ and $\delta^{13} \mathrm{C}$ from basal organic matter sources, zooplankton, fish muscle tissue and egesta of fishes, seabirds and pinnipeds was used to estimate trophic position for each group. We found a food web heavily dependent on pelagic productivity culminating with New Zealand fur seals and Hooker's sea lions. We compared multivariate concentration profiles of metals in the egesta of 4 trophic level groups from the Snares Islands with 4 similar trophic groups from the Auckland Islands. Results indicated more variation in concentration of bioactive metals in egesta among trophic level groups, than among islands. These results demonstrated that several potentially limiting micronutrients $(\mathrm{Mn}, \mathrm{Fe}, \mathrm{Co}$, $\mathrm{Zn}$ ) are bioaccumulated in the egesta of upper trophic levels of subantarctic food webs. The variance in concentration patterns of bioactive metals is more coincident with differences in food web structure than differences in water mass type surrounding the 2 islands. The patterns observed have important implications for understanding the interactions between food web architecture, biological vectors and productivity around the subantarctic islands of the Southern Ocean.
\end{abstract}

KEY WORDS: Southern Ocean $\cdot$ Iron $\cdot$ Seabird $\cdot$ Fish $\cdot$ Marine mammal $\cdot$ Nutrient vector

\section{INTRODUCTION}

In the pelagic regions of the Southern Ocean, the availability of iron limits productivity, resulting in vast regions of high-nutrient low-chlorophyll (HNLC) conditions (Martin et al. 1991, La Roche et al. 1996, Behrenfeld \& Kolber 1999, Boyd et al. 2000). These regions are punctuated by areas of high productivity surrounding the subantarctic islands where iron and other co-limiting nutrients (e.g. $\mathrm{Si}, \mathrm{Co}$ ) are made more freely available to phytoplankton (e.g. Blain et al. 2001) and to attached macroalgae (Walsh \& Hunter 1992). Nevertheless, fertilisation experiments in these regions have indicated that the high produc-

${ }^{*}$ Corresponding author: steve.wing@otago.ac.nz tivity surrounding some subantarctic islands cannot be fully accounted for by direct lithogenic inputs of iron (Blain et al. 2007, 2008). Indeed, iron directly supplied to the particulate pool from weathered rock or by aeolian deposition of dust is relatively insoluble in seawater at ambient $\mathrm{pH}$ and therefore little is directly available to phytoplankton (Jickells et al. 2005, Boyd et al. 2010). Alternatively, iron and other co-limiting metals assimilated within the marine food web may be accumulated in the form of sulphur-iron proteins, heme molecules and other organic forms, and passed on in the egesta of consumers directly to phytoplankton or bacteria (e.g. Hutchins et al. 1995, Frew et al. 2006). This biological pathway for recyc-

(C) The authors 2017. Open Access under Creative Commons by Attribution Licence. Use, distribution and reproduction are unrestricted. Authors and original publication must be credited. 
ling of limiting micronutrients highlights the potential importance of food web architecture for influencing primary production, particularly near islands in the Southern Ocean (e.g. Wing et al. 2014, Shatova et al. 2016).

The northern extreme of the Southern Ocean, the Subtropical Convergence (STC), marks a major oceanic division between the iron-limited subantarctic water to the south and macronutrient-limited ( $\mathrm{N}$ and P) subtropical waters to the north (e.g. BradfordGrieve et al. 1997, Frew et al. 2006). The STC is directed past the southern extreme of New Zealand by topographic steering on the Snares Plateau to form a wide Subtropical Frontal Zone (STFZ) (Smith et al. 2013). Within the largely oligotrophic subtropical waters to the north, oceanic islands provide hotspots for productivity as macronutrients from land stimulate phytoplankton blooms and growth of macroalgae (e.g. Harris et al. 1987, Gove et al. 2016). The STFZ itself stimulates a major source of pelagic productivity in the region as subantarctic and subtropical water mix along the convergence (BradfordGrieve et al. 1997). As a consequence, the STFZ provides an important foraging zone for seabirds and marine mammals, particularly in the vicinity of subantarctic islands where large breeding colonies of these species form (e.g. Shealer 2002, Hyrenbach et al. 2007, Bost et al. 2009). In these systems, feeding by top level predators can account for a large portion of the organic matter and nutrients supporting the oceanic food web, providing a potential mechanism for biological recycling of limiting nutrients (Trites et al. 1997, Karpouzi et al. 2007).

Accumulation of bioactive metals (e.g. Fe, Co, Zn) and macronutrients ( $\mathrm{N}$ and $\mathrm{P}$ ) within the marine food web can result in high concentrations within the egesta of consumers such as whales, pinnipeds and seabirds (e.g. Nicol et al. 2010, Roman \& McCarthy 2010, Lavery et al. 2014, Wing et al. 2014). For example, when at high population density, these consumers process large amounts of nitrogen and phosphate and can account for a significant portion of the $\mathrm{N}$ and $\mathrm{P}$ budget for the mixed layer in some regions (Roman \& McCarthy 2010, Roman et al. 2014). Here there is evidence that high trophic level species provide a vital ecological service as biological vectors by accumulating and redistributing limiting nutrients in both micronutrient- and macronutrient-limited systems (Lavery et al. 2010, Roman \& McCarthy 2010, McCauley et al. 2012). In this context, large high trophic level species such as whales and seabirds can act as important biological vectors capable of reshaping patterns in nutrient cycling and primary produc- tion across whole ecosystems (e.g. Roman et al. 2014, Schmitz et al. 2014, Doughty et al. 2016). Key to this hypothesis is an understanding of the mechanisms by which nutrients are processed within food webs and the role of food web structure and trophic position in accumulation and recycling of limiting nutrients. This raises the important question: Is there evidence for accumulation of bioactive trace metals within subantarctic island food webs?

To address this question, we examine patterns in concentrations of bioactive metals $(\mathrm{Mn}, \mathrm{Fe}, \mathrm{Co}, \mathrm{Ni}$, $\mathrm{Cu}, \mathrm{Zn}, \mathrm{As}, \mathrm{Cd}$ ) within the basal organic matter sources: suspended particulate organic matter (SPOM) and attached macroalgae, in the macrozooplankton (333 $\mu \mathrm{m}$ to $5 \mathrm{~mm}$ ) community and in the egesta of coastal fishes, seabirds and pinnipeds that make up the marine food web surrounding the subantarctic Snares Islands, New Zealand. We explicitly test whether patterns in the concentration of each bioactive metal in the egesta of organisms are coincident with trophic position of the contributing consumer. Here, trophic position is defined as the combination of trophic level and fraction of organic matter from SPOM versus macroalgae supporting the underlying food web, as indicated by analysis of $\delta^{13} \mathrm{C}$ and $\delta^{15} \mathrm{~N}$ (e.g. Lusseau \& Wing 2006, Jack \& Wing 2011). Further, we test whether variance in the composition of bioactive trace metals within the Snares Islands food web, which sits within the STFZ, and those in the Auckland Islands food web, which is surrounded by subantarctic water, is better explained by trophic position or by island of origin. Answers to these questions provide an explicit test of how patterns in accumulation of bioactive trace metals are shaped by food web architecture within subantarctic island food webs.

\section{MATERIALS AND METHODS}

\section{Sample collections}

Samples of SPOM were collected at 6 sites $(n=18)$ around the Snares Islands (Fig. 1) at the surface, and at 10 and $30 \mathrm{~m}$ depth using 101 Niskin bottles in austral summer 2012 and 2013. Each sample was passed through a $200 \mu \mathrm{m}$ mesh to remove zooplankton and detritus, and then filtered on pre-combusted GF/F filters in preparation for isotopic analysis. Samples of common Laminarian kelps Durvillaea antarctica and Ecklonia radiata were collected from 4 sites $(\mathrm{n}=11)$ in austral summer 2012 and 2013. Samples of the macrozooplankton community were collected using a $1 \mathrm{~m}^{2}$ 


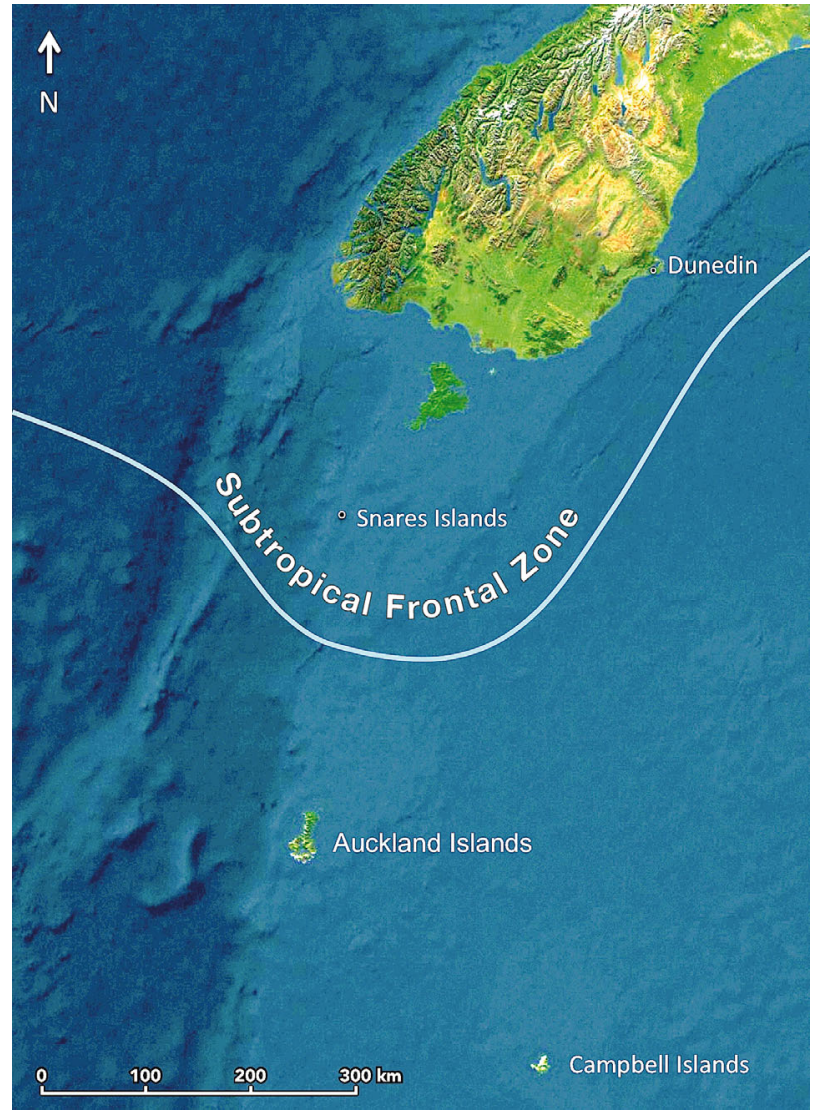

Fig. 1. Position of Snares Island and Auckland Island groups relative to the Subtropical Frontal Zone, the major division between modified subtropical water to the north and subantarctic water to the south

Tucker trawl with $333 \mu \mathrm{m}$ mesh nets from 3 coastal sites $(\mathrm{n}=11)$. Zooplankton species, which comprised predominately Calanus sp. and Neocalanus sp. copepods, the euphausid Nyctiphanes australis and solitary salps, were pooled for analysis. Paired samples of muscle tissue and faeces from 6 species of coastal fishes (banded wrasse Notolabrus fucicola, scarlet wrasse Pseudolabrus miles, trumpeter Latris lineata, small-scaled notothenid Notothenia microlepidota, blue cod Parapercis colias and sea perch Helicolenus percoides) were collected from 3 sites in 2012 and 2013 using hook and line, individually bagged and frozen for analysis $(n=67)$. Samples of guano from 8 species of seabird (southern black-backed gull Larus dominicanus, sooty shearwater Ardenna grisea, redbilled gull Larus novaehollandiae, cape pigeon Daption capense, Antarctic tern Sterna vittata, Snares crested penguin Eudyptes robustus, brown skua Stercorarius antarctica and Buller's albatross Thalassarche bulleri) and faeces of Hooker's sea lions Phocarctos hookeri and New Zealand fur seals Arctocephalus forsteri were collected using acid-washed plastic spoons and vials $(n=98)$. Samples were identified to species by observing animals producing egesta in situ. All biological samples were collected and handled using trace metal clean procedures.

\section{Isotope ratio mass spectrometry methods}

All sample types were freeze-dried at $-50^{\circ} \mathrm{C}$ for $24 \mathrm{~h}$ and ground to a fine powder using mortar and pestle. From each sample a 1 to $2 \mathrm{mg}$ subsample, depending on sample type, was weighed and sealed into a tin capsule for stable isotope analysis of $\delta^{13} \mathrm{C}$ and $\delta^{15} \mathrm{~N}$. Samples were analysed in the Department of Chemistry, University of Otago by combustion in an elemental analyser (Carlo Erba NA1500) to $\mathrm{CO}_{2}$ and $\mathrm{N}_{2}$. The isotopic compositions of the sample gases were measured by a Delta Advantage isotope ratio mass spectrometer (Thermo-Finnigan) operating in continuous flow mode. Raw delta values were normalised and reported against the international standards for carbon and nitrogen, Vienna Pee Dee Belemnite (VPDB) and atmospheric nitrogen (AIR), respectively. Normalisation was made by 3-point calibration with 2 glutamic acid international reference materials and a laboratory EDTA standard (Elemental Microanalysis) for carbon (USGS-40 $=-26.2 \%$, USGS-41 $=37.8 \%$, EDTA $=-38.52 \%$ ) and nitrogen (USGS-40 $=-4.52 \%$, USGS- $41=47.57 \%$, EDTA $=$ $-0.73 \%$ ). Time-based drift correction was calculated from the laboratory standard analysed at regular intervals with the samples. Analytical precision based on the replicate analyses of the quality control standard (EDTA, $\mathrm{n}=12$ ) was $0.2 \%$ for $\delta^{13} \mathrm{C}$ and $0.3 \%$ for $\delta^{15} \mathrm{~N}$.

\section{Trophic position using isotopic mixing models and trophic level}

The $\delta^{13} \mathrm{C}$ and $\delta^{15} \mathrm{~N}$ of phytoplankton were characterised by calculating a stratified mean by site and depth from SPOM samples collected in 2012 and 2013. The $\delta^{13} \mathrm{C}$ and $\delta^{15} \mathrm{~N}$ of macroalgae were characterised with a stratified mean by site and species from samples of the dominant kelps Ecklonia radiata and Durvillaea antarctica collected from 4 shore stations in 2012 and 2013.

In order to estimate the relative contributions of 2 organic matter source pools to the food web supporting a consumer, one first needs an estimate of trophic 
level to accurately apply trophic enrichment to values of $\delta^{13} \mathrm{C}$ (e.g. Wing et al. 2008). Similarly, in order to accurately determine the trophic level of a consumer, one first needs an estimate of the relative contributions of organic matter source pools to accurately estimate baseline $\delta^{15} \mathrm{~N}\left(\delta^{15} \mathrm{~N}_{\text {base }}\right)$ (e.g. Wing \& Jack 2012). To simultaneously solve these 2 problems, a 2-step iterative procedure was used to determine the basal organic matter used and the trophic level of each individual consumer, fish, seabird or pinniped (Jack \& Wing 2011, Wing et al. 2012). In this case, we used muscle tissue of fishes to estimate trophic position, while trophic position of seabirds and marine mammals was estimated from samples of guano or faeces. Firstly, an individual-based 2-source mass balance model after Phillips \& Gregg (2001) was used to calculate the relative contribution of SPOM and macroalgae using $\delta^{13} \mathrm{C}$. In this step, an approximation of trophic level based on literature values was used to estimate trophic discrimination of $\delta^{13} \mathrm{C}$. The results were then used to estimate the corresponding $\delta^{15} \mathrm{~N}$ of the mixture of organic matter sources supporting each individual $\left(\delta^{15} \mathrm{~N}_{\text {base }}\right)$. Trophic level was then calculated for each individual from $\delta^{15} \mathrm{~N}_{\text {baser }}$ as $\left(\delta^{15} \mathrm{~N}_{\text {consumer }}-\delta^{15} \mathrm{~N}_{\text {base }} / \Delta_{\mathrm{n}}\right)$ for estimates from muscle tissue and $\left(\delta^{15} \mathrm{~N}_{\text {consumer }}-\right.$ $\left.\delta^{15} \mathrm{~N}_{\text {base }} / \Delta_{\mathrm{n}}\right)+1$ for estimates from egested material (e.g. Wing et al. 2014), where $\Delta_{\mathrm{n}}$ is the trophic discrimination factor, after Post (2002). The resulting estimate of trophic level was then iterated back into the mass balance model until a stable solution was obtained for both the mixture of organic matter sources and trophic level for each individual. We used the average trophic discrimination factors for aquatic environments of $+0.4 \%$ ( SE 0.17 ) for $\Delta^{13} \mathrm{C}$, and $+2.3 \%$ (SE 0.28 ) for $\Delta^{15} \mathrm{~N}$, after McCutchan et al. (2003), for each enrichment step.

\section{Inductively coupled plasma-mass spectrometry methods}

Samples of fish faeces, seabird guano and pinniped faeces were freeze-dried in acid-washed high-density polyethyene (HDPE) vials. Each sample was then ground into a fine powder using acid-washed HDPE rods. A $0.2 \mathrm{~g}$ subsample of each sample was cold digested using $10 \mathrm{ml}$ of high-purity quartz distilled (QD) $\mathrm{HNO}_{3}$ for $1 \mathrm{~h}$ in acid-washed perfluoroalkaloxy CEM microwave tubes, then hot digested in a CEM MARS6 microwave at $180^{\circ} \mathrm{C}$ for $40 \mathrm{~min}$. When cooled, digested samples were dried down on a hot block and re-dissolved using $1 \mathrm{ml} \mathrm{QD} \mathrm{HNO}_{3}$, diluted up to $25 \mathrm{ml}$ using Milli-Q filtered water (Millipore) then further diluted 10:1 using Milli-Q water.

An Agilent 7500ce quadrupole inductively coupled plasma-mass spectrometer (ICP-MS) with an octopole collision cell and autosampler was used for the analysis of elemental concentrations in guano and faeces samples. The bioactive metals $\mathrm{Mn}, \mathrm{Fe}, \mathrm{Co}, \mathrm{Ni}$, $\mathrm{Cu}, \mathrm{Zn}, \mathrm{As}$ and $\mathrm{Cd}$ were of primary interest but other elements (Li, Na, Mg, Al, K, Ca, V, Cr, Ga, Se, Rb, Sr, $\mathrm{Ag}, \mathrm{Cs}, \mathrm{Ba}, \mathrm{Pb}$ and $\mathrm{U}$ ) were measured to establish matrix composition and possible interferences. Dilutions of the sample digests and blanks in $2 \% \mathrm{v} / \mathrm{v}$ $\mathrm{HNO}_{3}$ were spiked offline with a cocktail of 6 reference elements to compensate for any drift or possible matrix effects. Calibration standards were prepared by serial dilution of a SPEX CertiPrep multi-element standard (NIST traceable). The ICP-MS was tuned according to the manufacturer's recommendations for robust conditions to minimise interferences and instrumental drift. Where possible multiple isotopes of the analyte elements were measured to confirm the absence of interferences.

The accuracy of this single step measurement was established with several certified reference materials. The analysis of microwave-assisted digestions of 3 biological reference materials for the elements of interest gave recoveries typically within $5 \%$ of expected values, while the digestion of a mineral reference material produced recoveries within $2 \%$ of certified values.

\section{Statistical analysis}

Ward's hierarchical clustering was applied to data on trophic level and \% SPOM in underlying food web for a combined data set of 24 species from the Snares and Auckland Islands marine food webs (JMP Pro10). Results were used to classify Species (24 levels, fixed) into Trophic level group (4 levels, fixed). ANOVA was then used to test for differences in concentrations of each of the primary bioactive metals ( $\mathrm{Mn}, \mathrm{Fe}, \mathrm{Co}, \mathrm{Ni}, \mathrm{Cu}, \mathrm{Zn}, \mathrm{As}$ and $\mathrm{Cd}$ ) by Species (24 levels, fixed) nested within Trophic level group (4 levels, fixed) for a combined data set from samples of egesta from coastal fishes (6 species), seabirds (16 species) and 2 pinniped species from the Snares and Auckland Islands food webs (see Tables 1 \& 2) (Wing et al. 2014). Tukey's post hoc tests were performed for pair-wise comparisons within Trophic level group (JMP Pro10). To test whether trophic level groups were distinguishable by multivariate concentrations of bioactive metals 
(Mg, Mn, Fe, Co, Ni, Cu, Zn, As and $\mathrm{Cd}$ ), we first performed a discriminant function analysis (DFA) to test reclassification success. Further, a permutational multivariate analysis of variance (PERMANOVA) was carried out with factors Trophic level group (4 levels, fixed) and Island (2 levels, fixed) to test whether variance in bioactive metal concentrations was associated with food web structure or island of origin. Here the concentration data for $\mathrm{Mg}, \mathrm{Al}, \mathrm{Sr}, \mathrm{Mn}, \mathrm{Fe}, \mathrm{Co}, \mathrm{Ni}, \mathrm{Cu}$, $\mathrm{Zn}, \mathrm{As}$ and $\mathrm{Cd}$ were normalised and then combined into a similarity matrix using a Euclidean distance-based similarity algorithm (Anderson et al. 2008). A main test and then multiple pairwise tests were carried out in PERMANOVA+ (Primer 6.0) (Anderson et al. 2008).
Table 1. Mean (SE) $\delta^{15} \mathrm{~N}, \delta^{13} \mathrm{C}$, trophic level (TL) and fraction of suspended particulate organic matter (SPOM) supporting the underlying food web, based on individual level mass-balance analysis, for organic matter source pools, fish muscle tissue, and egesta of seabirds and marine mammals from the Snares Islands

\begin{tabular}{|c|c|c|c|c|}
\hline Species & $\delta^{15} \mathrm{~N}(\mathrm{SE})$ & $\delta^{13} \mathrm{C}(\mathrm{SE})$ & TL (SE) & $\begin{array}{c}\text { Fraction } \\
\text { SPOM (SE) }\end{array}$ \\
\hline SPOM & $3.86(0.16)$ & $-22.70(0.26)$ & 0 & 1 \\
\hline Macroalgae (Laminarians) & $6.94(0.13)$ & $-15.99(0.31)$ & 0 & 0 \\
\hline Sea perch & $10.91(0.25)$ & $-19.52(0.23)$ & $2.64(0.08)$ & $0.68(0.03)$ \\
\hline Blue cod & $11.01(0.11)$ & $-19.61(0.15)$ & $2.70(0.06)$ & $0.70(0.02)$ \\
\hline Small-scaled notothenid & $11.35(0.17)$ & $-19.28(0.15)$ & $2.80(0.06)$ & $0.65(0.02)$ \\
\hline Trumpeter & $12.28(0.32)$ & $-18.87(0.20)$ & $3.13(0.12)$ & $0.59(0.03)$ \\
\hline Scarlet wrasse & $12.50(0.55)$ & $-19.94(0.16)$ & $3.48(0.26)$ & $0.79(0.03)$ \\
\hline Banded wrasse & $13.51(0.36)$ & $-19.57(0.28)$ & $3.88(0.16)$ & $0.76(0.04)$ \\
\hline Black-backed gulla $^{\mathrm{a}}$ & $5.34(0.37)$ & $-14.19(0.66)$ & $1.67(0.36)$ & $0.13(0.08)$ \\
\hline Sooty shearwater ${ }^{\mathrm{a}}$ & $5.43(0.65)$ & $-26.75(0.26)$ & $1.68(0.28)$ & $1(0.00)$ \\
\hline Red-billed gull ${ }^{\mathrm{a}}$ & $7.08(0.41)$ & $-19.87(0.19)$ & $2.10(0.17)$ & $0.77(0.02)$ \\
\hline Cape pigeon ${ }^{\mathrm{a}}$ & $7.72(0.75)$ & $-21.87(0.36)$ & $2.56(0.35)$ & $0.96(0.02)$ \\
\hline Antarctic tern ${ }^{\mathrm{a}}$ & $8.24(0.68)$ & $-21.78(0.27)$ & $2.82(0.31)$ & $0.95(0.02)$ \\
\hline Snares crested penguin ${ }^{a}$ & $9.75(1.29)$ & $-23.95(0.33)$ & $3.56(0.56)$ & $1.0(0.00)$ \\
\hline Brown skua $^{\mathrm{a}}$ & $10.79(0.17)$ & $-21.78(0.29)$ & $3.94(0.08)$ & $0.95(0.01)$ \\
\hline Buller's albatross $^{\mathrm{a}}$ & $11.16(0.65)$ & $-23.06(0.43)$ & $4.17(0.28)$ & $1.0(0.00)$ \\
\hline New Zealand fur seal ${ }^{\mathrm{a}}$ & $13.88(0.85)$ & $-21.29(0.26)$ & $5.33(0.37)$ & $0.98(0.01)$ \\
\hline Hooker's sea lion ${ }^{\mathrm{a}}$ & $14.73(0.54)$ & $-20.48(0.20)$ & $5.64(0.25)$ & $0.94(0.02)$ \\
\hline
\end{tabular}

\section{RESULTS}

Cluster analysis of the trophic position of fishes, based on isotopic analysis of muscle tissue, and seabirds and pinnipeds, as indicated by analysis of egesta, demonstrated distinct patterns among foraging guilds at the Snares Islands. Coastal foragers were represented by the southern black-backed gull; pelagic foragers included the sooty shearwater, redbilled gull, sea perch, blue cod, small-scaled notothenid, cape pigeon, Antarctic tern and trumpeter; higher trophic level predator species included scarlet wrasse, Snares crested penguin, brown skua, Buller's albatross and banded wrasse; and upper level predators were represented by the 2 pinniped species New Zealand fur seal and Hooker's sea lion (Table 1, Fig. 2). These 4 distinct trophic level groups were then used in subsequent ANOVA analyses.

Concentrations of the primary bioactive metals $\mathrm{Fe}$, $\mathrm{Mn}, \mathrm{Co}$ and $\mathrm{Zn}$ in phytoplankton, kelp, macrozooplankton and in the egesta of consumers within the Snares Islands food web showed large differences among some Species and Trophic level group (Table 2, Fig. 3). Results of ANOVA on Species nested within Trophic level group demonstrated differences in concentration of each of the bioactive trace metals $(\mathrm{Mn}, \mathrm{Fe}, \mathrm{Co}, \mathrm{Ni}, \mathrm{Zn}, \mathrm{Cu}, \mathrm{As}$ and $\mathrm{Cd}$ )

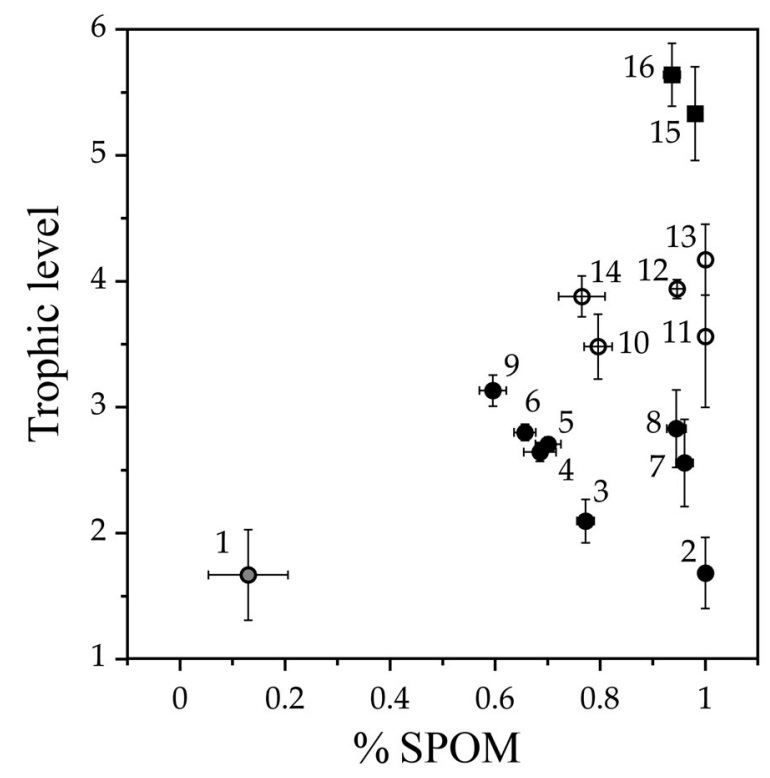

Fig. 2. Trophic position of fishes, seabirds and pinnipeds at the Snares Islands identified by trophic level group: (O) coastal foragers - (1) southern black-backed gulli $(\mathbf{O})$ pelagic foragers (2) sooty shearwater, (3) red-billed gull, (4) sea perch, (5) blue cod, (6) small-scaled notothenid, (7) cape pigeon, (8) Antarctic tern, (9) trumpeter; $(O)$ pelagic predator - (10) scarlet wrasse, (11) Snares crested penguin, (12) brown skua, (13) Buller's albatross, (14) banded wrasse; (ם) pinnipeds-(15) New Zealand fur seal, (16) Hooker's sea lion (Table 1). SPOM: suspended particulate organic matter. Error bars indicate $\pm 1 \mathrm{SE}$ 


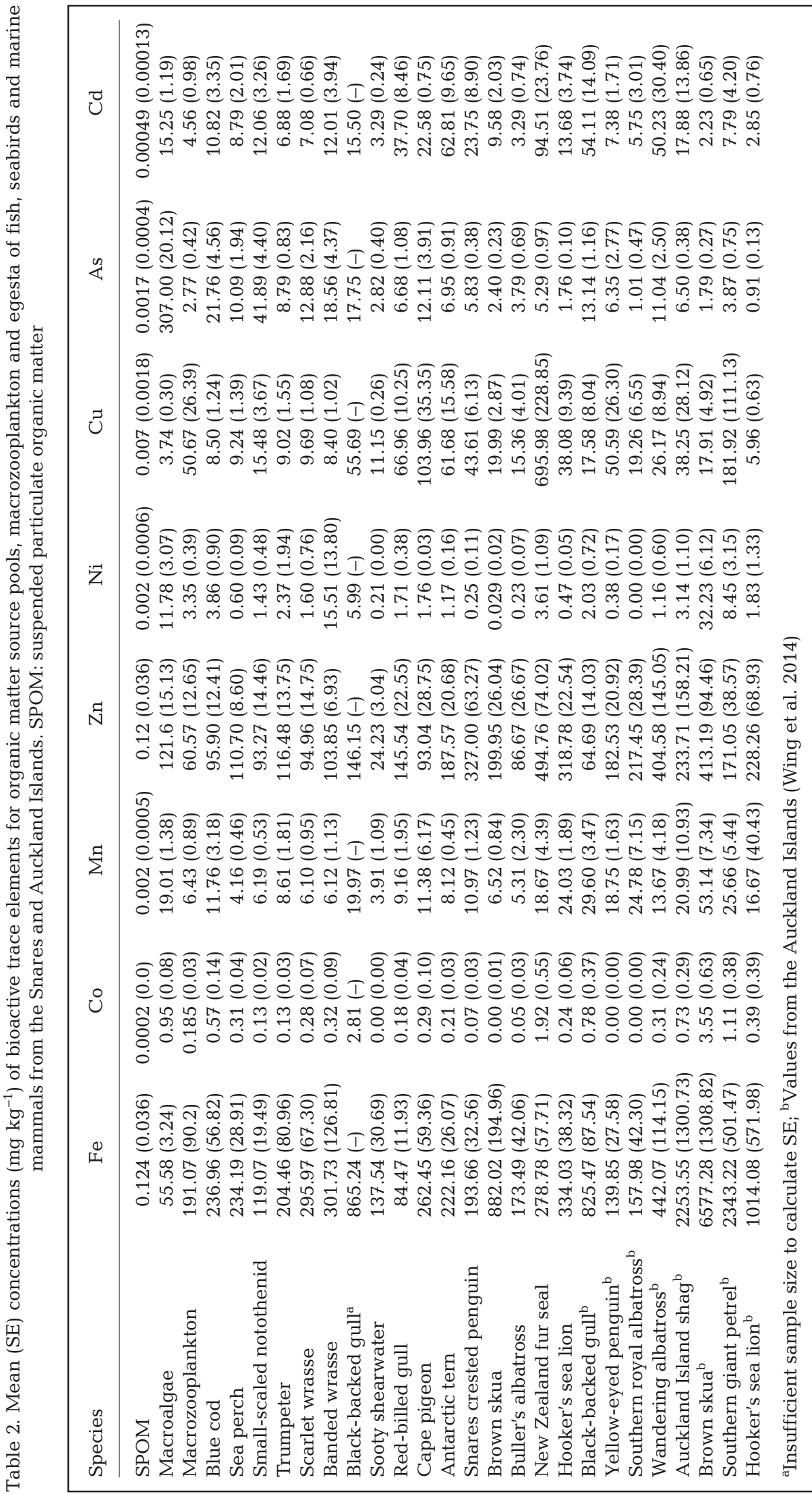

within Trophic level group (Table 3, Fig. 4). Results of the DFA demonstrated that each Trophic level group was distinguishable by the multivariate concentrations of bioactive metals. Here only 2 out of 24 groups were misclassified, both reciprocal misclassifications between pelagic foragers and pelagic predators, with the test achieving $91.67 \%$ classification success (Fig. 5). Species occurring both at the Snares Islands and the Auckland Islands were treated in separate groupings by Island.

The results of the PERMANOVA+ analysis of multiple concentrations of trace metals demonstrated differences within Trophic level group, but not a significant difference within Island (Main test: Island: pseudo$F=2.60, \mathrm{p}=0.06$; Trophic level group: pseudo- $F=5.0, \mathrm{p}=0.001$. Pairwise tests: coastal foragers [a], pelagic foragers $[\mathrm{b}]$, pelagic predators [c], pinnipeds [c]. Different letters after the groups indicate a significant difference).

\section{DISCUSSION}

The analyses and results presented here provide evidence for the accumulation of biologically active metals $(\mathrm{Mn}, \mathrm{Fe}, \mathrm{Co}, \mathrm{Ni}$, $\mathrm{Cu}, \mathrm{Zn}, \mathrm{As}$ and $\mathrm{Cd}$ ) within subantarctic island food webs supporting high trophic level fish, seabirds and marine mammals. Specifically iron, a key limiting micronutrient, can be found in concentrations 2 to 3 orders of magnitude higher in the egesta of fish, seabirds and marine mammals than in the organic matter source pools surrounding the subantarctic Snares Islands, and relative to particulate pools in the subantarctic water mass (Fig. 3, Table 2) (Frew et al. 

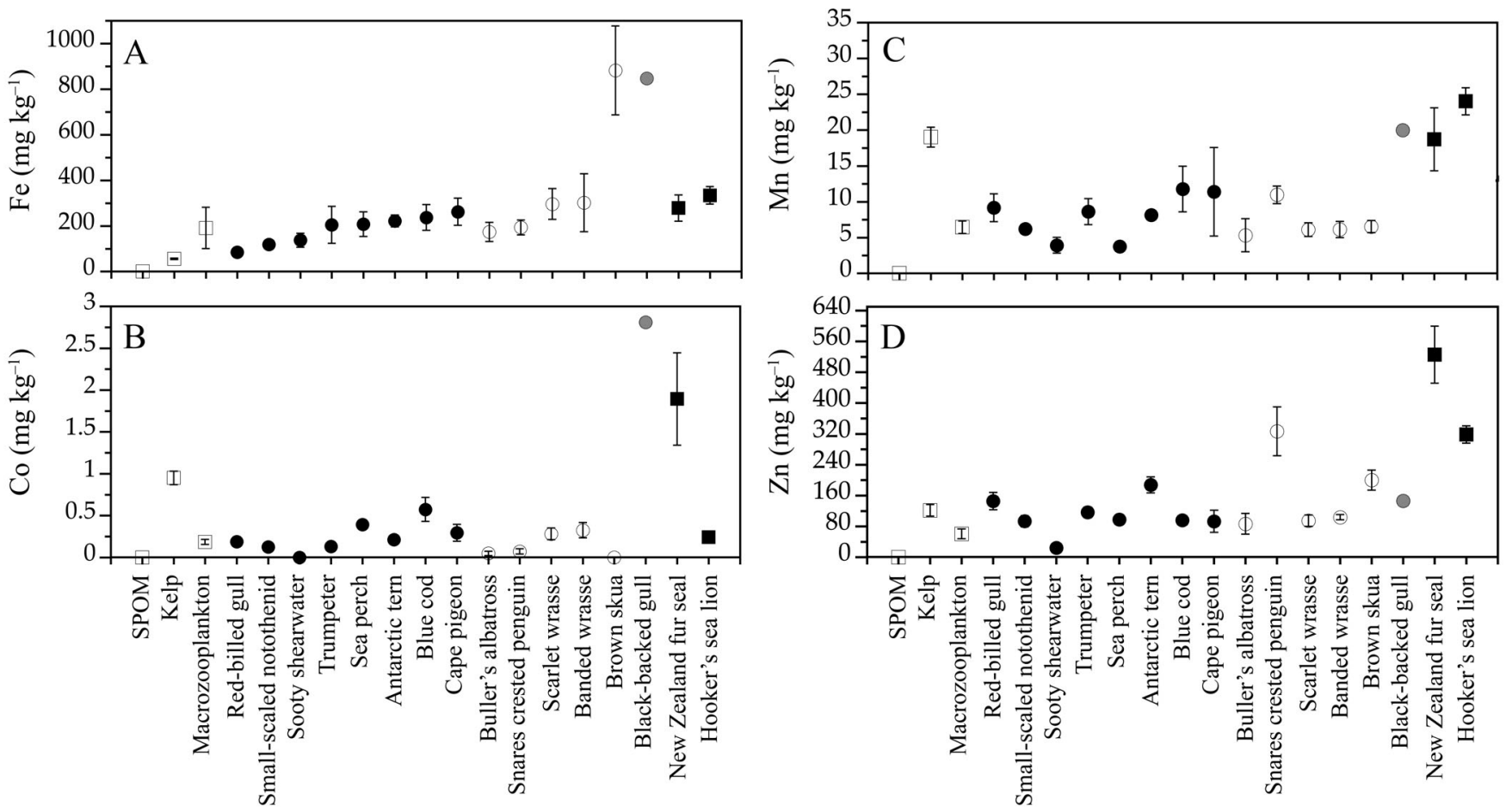

Fig. 3. Concentration ( $\mathrm{mg} \mathrm{kg}^{-1}$ ) of (A) Fe, (B) $\mathrm{Co},(\mathrm{C}) \mathrm{Mn}$ and (D) Zn in phytoplankton (suspended particulate organic matter, SPOM), kelp, macrozooplankton and in the egesta of fishes, seabirds and pinnipeds in the Snares Islands food web. Trophic level groups: $(\square)$ organic matter sources and macrozooplankton, $(\bullet)$ pelagic foragers, $(\bigcirc)$ pelagic predators, $(\bigcirc)$ coastal forager, ( pinnipeds. Error bars indicate $\pm 1 \mathrm{SE}$

2006). Potentially co-limiting micronutrients, such as $\mathrm{Mn}, \mathrm{Co}$ and $\mathrm{Zn}$, are also highly concentrated within the food webs in this system relative to concentrations in organic matter source pools (Table 2, Fig. 3). These data have important implications for our understanding of the interactions between food web architecture and the role of fishes, seabirds and marine mammals as biological nutrient vectors in the

Table 3. Results from ANOVA for Species nested within Trophic level group for each of the bioactive trace metals ( $\mathrm{Mn}, \mathrm{Fe}, \mathrm{Co}, \mathrm{Ni}, \mathrm{Cu}, \mathrm{Zn}, \mathrm{As}, \mathrm{Cd}$ ). Results are given for the main test and for a Tukey's post hoc test on Trophic level group. Degrees of freedom for each model are $F_{24,154}$, trophic level groups are defined as (1) pelagic foragers, (2) pelagic predators, (3) coastal foragers and (4) pinnipeds. Different letters following the groups indicate significant differences

\begin{tabular}{|lrccl|}
\hline Element & F-ratio & $\mathrm{p}$ & $\mathrm{r}^{2}$ & \multicolumn{1}{c|}{ Tukey's test } \\
\hline $\mathrm{Mn}$ & 3.82 & $<0.0001$ & 0.37 & $1(\mathrm{a}), 2(\mathrm{a}), 3(\mathrm{ab}), 4(\mathrm{~b})$ \\
$\mathrm{Fe}$ & 24.30 & $<0.0001$ & 0.79 & $1(\mathrm{a}), 2(\mathrm{~b}), 3(\mathrm{ab}), 4(\mathrm{a})$ \\
$\mathrm{Co}$ & 9.61 & $<0.0001$ & 0.59 & $1(\mathrm{a}), 2(\mathrm{~b}), 3(\mathrm{c}), 4(\mathrm{~b})$ \\
$\mathrm{Ni}$ & 20.39 & $<0.0001$ & 0.76 & $1(\mathrm{a}), 2(\mathrm{~b}), 3(\mathrm{ab}), 4(\mathrm{a})$ \\
$\mathrm{Cu}$ & 8.33 & $<0.0001$ & 0.56 & $1(\mathrm{a}), 2(\mathrm{a}), 3(\mathrm{a}), 4(\mathrm{~b})$ \\
$\mathrm{Zn}$ & 5.02 & $<0.0001$ & 0.44 & $1(\mathrm{a}), 2(\mathrm{~b}), 3(\mathrm{ab}), 4(\mathrm{c})$ \\
$\mathrm{As}$ & 17.39 & $<0.0001$ & 0.73 & $1(\mathrm{a}), 2(\mathrm{~b}), 3(\mathrm{a}), 4(\mathrm{c})$ \\
$\mathrm{Cd}$ & 5.88 & $<0.0001$ & 0.47 & $1(\mathrm{a}), 2(\mathrm{a}), 3(\mathrm{ab}), 4(\mathrm{~b})$ \\
\hline
\end{tabular}

vicinity of the subantarctic islands of the Southern Ocean.

Our analysis of the trophic structure among fishes, seabirds and pinnipeds inhabiting the Snares Islands indicates a food web supported by both macroalgal and pelagic productivity, culminating in Hooker's sea lion at the highest trophic level considered here (Table 1, Fig. 2). Patterns in the trophic position, a combination of trophic level and the composition of organic matter supporting the diet of a species, of 6 reef fishes, 8 seabird species and 2 pinnipeds with breeding colonies on the Snares Islands indicate 4 primary trophic level groups (Fig. 2). Coastal foragers, represented by the southern black-backed gull, had a relatively low trophic level diet with a large component $(87 \%$ ) supported by organic matter originating from macroalgae or recycled organic matter from the benthic food web. This is consistent with observations at the Auckland Islands of blackbacked gulls feeding on limpets, crabs and bivalves in intertidal food webs (e.g. Wing et al. 2014). Pelagic foragers such as sooty shearwater, red-billed gull, cape pigeon, Antarctic tern, trumpeter, blue cod and small-scaled notothenid had trophic levels between 1.5 and 3.2, with diets obtained from food webs primarily supported by organic matter from SPOM but 

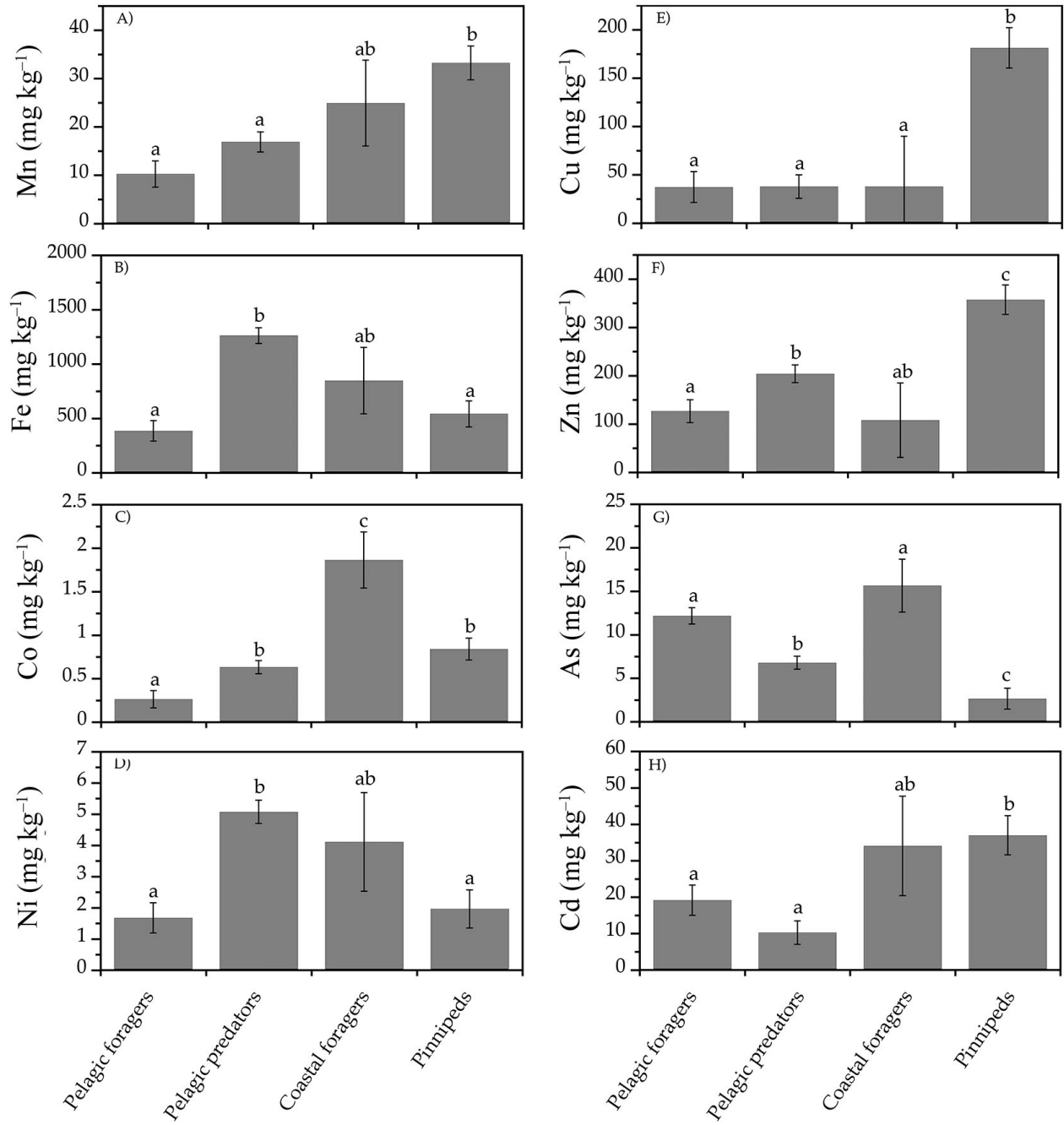

Fig. 4. Results from a combined analysis of trace element concentrations in coastal foragers, pelagic foragers, pelagic predators, and pinnipeds from the Snares Islands and the Auckland Islands (Wing et al. 2014). (A) Mn, (B) Fe, (C) Co, (D) Ni, (E) Cu, (F) Zn, (G) As,

$(\mathrm{H}) \mathrm{Cd}$. Different letters above the bars indicate significant differences (Table 3)

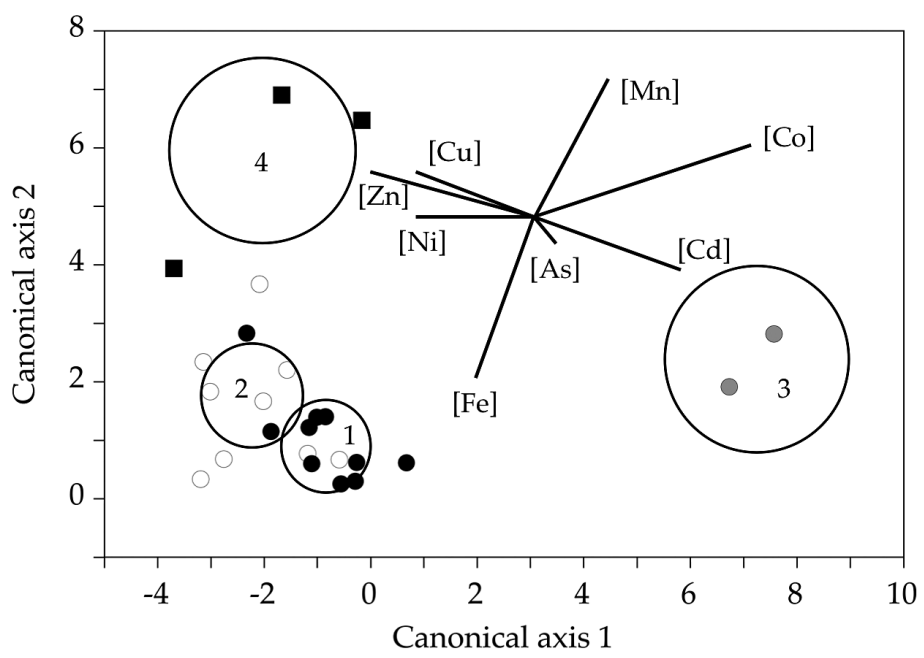

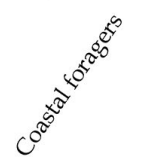

with up to $41 \%$ contribution from macroalgae. These species feed on small fish and macrozooplankton in the vicinity of the islands. Higher trophic level pelagic predators such as Snares crested penguin, brown skua, Buller's albatross, banded wrasse and scarlet wrasse had trophic levels between 3.5 and 4.2, with a diet obtained from food webs supported primarily by SPOM and with up to $24 \%$ of organic matter originating from macroalgae. Top predators such as the New Zealand fur seal and Hooker's sea lion were linked to food webs primarily supported by pelagic productivity and had trophic levels in excess of 5, indicating feeding on fish and squid as well as predation at the upper levels of the food web.

While estimates of trophic position based on stable isotope analysis $\left(\delta^{13} \mathrm{C}\right.$ and $\left.\delta^{15} \mathrm{~N}\right)$ using muscle tissue reflect a long-term integration of diet, estimates based on analysis of egested material only reflect the most recent meal (e.g. Wing et al. 2014). Further, egested material, particularly seabird guano, is subject to significant volatilisation of ammonia and associated influences on $\delta^{15} \mathrm{~N}$. Accordingly, care was taken in the present study to collect multiple replicates of fresh material where possible in order to accurately reflect the trophic position of seabirds and pinnipeds, and

Fig. 5. Canonical plot from discriminant function analysis (DFA) of bioactive metal concentrations in the egesta of fishes, seabirds and marine mammals from both the Auckland Islands and Snares Islands marine food webs. Species are categorised by Trophic level group: ( 1) pelagic foragers, (○ 2) pelagic predators, (○ 3) coastal foragers, $(\mathbf{\square})$ pinnipeds. Ellipses represent $95 \%$ confidence limits for DFA. Biplot rays represent the relative contribution of each element to canonical axis variation. DFA resulted in $91.67 \%$ correct (2/24 misclassified) classification by Trophic level group 
reduce variability in $\delta^{15} \mathrm{~N}$ associated with weathering. Each of these estimates was compared with available information on diet and foraging ecology of the species in question. Estimates of trophic position can also be influenced by significant variation in trophic discrimination factors $\left(\Delta^{13} \mathrm{C}\right.$ and $\left.\Delta^{15} \mathrm{~N}\right)$ among consumers (e.g. Newsome et al. 2009). This is particularly important when considering low trophic level species. For estimates at higher trophic levels, trophic discrimination factors become averaged across multiple trophic levels, so it becomes appropriate to use average values for specific environments (e.g. McCutchan et al. 2003).

We have analysed patterns of bioactive metal concentrations in the egesta of consumers among 4 distinct trophic level groups from the Snares Islands food web, and within the egested material from consumers from 4 overlapping trophic level groups from the Auckland Islands food web (Table 2) (Wing et al. 2014). Results of these analyses provide evidence for high concentrations of bioactive trace metals in the egesta of coastal foraging species, and generally increasing concentrations in the egesta within the pelagic-based food web, from pelagic foragers to pelagic predators (Table 3, Fig. 4). Using a multivariate analysis (DFA) of bioactive metal concentrations, we then asked whether the egesta of individual species could be accurately classified according to our independently defined trophic level groups. We found that $91.67 \%$ of species were correctly classified from trace metal concentration data of egesta by trophic level group, with only 2 out of the 24 species considered reciprocally misclassified between the pelagic foragers group and the pelagic predators group (Fig. 5). These analyses provide evidence for a specific trace metal fingerprint associated with trophic position.

In these analyses, the primary limiting micronutrients $\mathrm{Mn}, \mathrm{Fe}$, Co and $\mathrm{Zn}$, as well as the important subantarctic bioactive metal $\mathrm{Cd}$, were most important for discriminating egesta among trophic level groups (Fig. 5). While we observe that each of the primary micronutrients ( $\mathrm{Fe}, \mathrm{Co}, \mathrm{Zn}$ and $\mathrm{Mn}$ ) can be found at higher concentrations in the egested material of some higher trophic level species (e.g. Fig. 3), there is no simple relationship between concentration of these elements and trophic level of the consumer. Here, the composition of organic matter sources supporting the food web is likely as important as the trophic level for influencing bioaccumulation of metals. For example, concentrations of $\mathrm{Co}$ and $\mathrm{Mn}$ were found to be relatively high in macroalgae at the Snares Islands (Table 2, Fig. 3). Among the con- sumers, this is reflected in high concentrations of Co and $\mathrm{Mn}$ in the egested material from black-backed gulls, which feed in the coastal margin on prey predominately supported by macroalgae (Table 2, Fig. 2). While this pattern is consistent with observations from the Auckland Islands, our trace metal results for black-backed gulls from the Snares Islands are based on a limited sample size (Table 2). Cobalt may be accumulated in the food web as cobalamin (vitamin $\mathrm{B}_{12}$ ), which is necessary for the growth of phytoplankton and for the production of red blood cells in vertebrates. Similarly, iron is found at relatively high concentrations in macrozooplankton, which use iron in several important enzymatic functions. This can account for a large portion of the organically bound iron in the Southern Ocean (Nicol et al. 2010). We observed a step change in iron concentrations between the basal organic matter sources and macrozooplankton that was then reflected in the iron concentrations in the egested material of pelagic foragers and predators (Fig. 3). Another step change in iron concentrations was observed in the egested material from brown skua, which opportunistically scavenge carrion of marine mammals and prey on other seabird species. Brown skua guano had the highest observed iron concentrations within both the Snares and Auckland Islands food webs (Table 2).

The patterns that we observed provide specific evidence that the concentration of bioactive trace metals $(\mathrm{Mn}, \mathrm{Fe}, \mathrm{Co}, \mathrm{Ni}, \mathrm{Cu}, \mathrm{Zn}, \mathrm{As}$ and $\mathrm{Cd}$ ) in the egested material from coastal fishes, seabirds and pinnipeds is tightly linked to food web structure and trophic position. In order to investigate variation in this pattern among food webs from different oceanographic regions, we used a PERMANOVA to test whether the variance in concentrations of multiple bioactive metals, or the trace metal 'fingerprint' of egesta, was better explained by trophic position of consumers or by island of origin. We found evidence for significant differences in trace metal composition in egesta among trophic level groups but not as much variation between groups from different islands. These results demonstrate that bioactive metal concentrations within the biological pool are more influenced by physiological accumulation within the subantarctic food webs than by the ambient conditions in the water column surrounding the islands. Here, we compared egesta samples from the Snares Islands, which are surrounded by modified subtropical waters within the STFZ, with egesta samples from the Auckland Islands, which are surrounded by micronutrient-limited subantarctic waters (Frew et al. 2006). 
While our results are primarily observational in nature, they suggest several likely ecological mechanisms operating within subantarctic food webs, which are important for nutrient recycling and maintenance of productivity patterns. The first is that many of the species we consider (e.g. albatrosses, penguins and oceanic feeding pinnipeds) make extensive foraging bouts targeting oceanic frontal systems and regions of the ocean with hotspots of productivity (e.g. Imber 1999, Anderson et al. 2010), and consequently accumulate prey rich in the limiting nutrients of the Southern Ocean (i.e. Mn, Fe, Co, Zn and other bioactive trace metals). By congregating at the subantarctic islands and depositing egested material both on the islands and in the surrounding waters, these species may act as biological vectors redistributing limiting nutrients in the ecosystem. A second mechanism likely at play is that many of the upper trophic level species (e.g. brown skua, Hooker's sea lion) actively prey on, or opportunistically feed on the carrion of, seabirds and marine mammals, both rich sources of bioactive metals. In this case, the accumulation of iron in heme molecules in blood and myoglobin, and other sulphur-iron proteins results in high concentrations of bioavailable iron in the egested material from these species. Evidence for the extensive predation by brown skua on oceanic seabirds (Pietz 1987) supports this idea. In addition, recent analysis of egested material from Hooker's sea lions inhabiting both the Snares and Auckland Islands indicates that a large component of their diet comprises New Zealand fur seals (L. C. Wing et al. unpubl. data), a rich source of bioactive metals, particularly iron.

We have found strong interactions between food web architecture and accumulation of high concentrations of bioactive metals in the subantarctic ecosystem, with increasing concentrations of bioactive metals found in the egested material from top predatory species. Extensive foraging bouts by seabirds and marine mammals to frontal systems, and other hotspots of productivity, likely act to collect limiting nutrients from far afield of the subantarctic islands. By feeding at multiple trophic levels, direct predation and carrion feeding, high trophic level species accumulate and redistribute high concentrations of the bioactive metals that limit primary productivity in the Southern Ocean. Experimental additions of guano from these species in both subantarctic and subtropical water masses stimulates phytoplankton productivity, raising the possibility that seabirds enhance production in the vicinity of the subantarctic islands (Shatova et al. 2016). These data highlight how food web architecture interacts with biogeochemical cycling and the important role of coastal fishes, seabirds and marine mammals in the subantarctic ecosystem as biological nutrient vectors. Our results provide important evidence for how the maintenance of intact food webs and biodiversity on these islands contributes to the maintenance of ecosystem function in the Southern Ocean.

Acknowledgements. We thank Melanie Gault-Ringold, David Barr, Bill Dickson, Phil Heseltine, Russell Frew and Trudi Webster for assistance with this work. Access to the Snares Islands was provided by New Zealand's Department of Conservation, and samples were collected under permits from the Department of Conservation, University of Otago Animal Ethics Committee and the Ministry for Primary Industries. Support from the Royal Society of New Zealand's Marsden Fund (UOO1008) to S.R.W. made this work possible.

\section{LITERATURE CITED}

Anderson M, Gorley R, Clarke K (2008) PERMANOVA+ for PRIMER: Guide to software and statistical methods. University of Auckland, Auckland

Anderson ORJ, Phillips RA, Shore RF, McGill RAR, McDonald RA, Bearhop S (2010) Element patterns in albatrosses and petrels: influence of trophic position, foraging range, and prey type. Environ Pollut 158:98-107

Behrenfeld MJ, Kolber ZS (1999) Widespread iron limitation of phytoplankton in the South Pacific Ocean. Science 283:840-843

Blain S, Treguer P, Belviso S, Bucciarelli E and others (2001) A biogeochemical study of the island mass effect in the context of the iron hypothesis: Kerguelen Islands, Southern Ocean. Deep-Sea Res I 48:163-187

* Blain S, Queguiner B, Armand L, Belviso S and others (2007) Effect of natural iron fertilization on carbon sequestration in the Southern Ocean. Nature 446:1070-1074

* Blain S, Sarthou G, Laan P (2008) Distribution of dissolved iron during the natural iron-fertilization experiment KEOPS (Kerguelen Plateau, Southern Ocean). Deep-Sea Res II 55:594-605

Bost C, Cotte C, Bailleul F, Cherel Y and others (2009) The importance of oceanographic fronts to marine birds and mammals of the southern oceans. J Mar Syst 78: 363-376

Boyd PW, Watson AJ, Law CS, Abraham ER and others (2000) A mesoscale phytoplankton bloom in the polar Southern Ocean stimulated by iron fertilization. Nature 407:695-702

Boyd PW, Mackie DS, Hunter KA (2010) Aerosol iron deposition to the surface ocean-Modes of iron supply and biological responses. Mar Chem 120:128-143

Bradford-Grieve J, Chang F, Gall M, Pickmere S, Richards F (1997) Size-fractionated phytoplankton standing stocks and primary production during austral winter and spring 1993 in the Subtropical Convergence region near New Zealand. NZ J Mar Freshw Res 31:201-224

* Doughty CE, Roman J, Faurby S, Wolf A and others (2016) Global nutrient transport in a world of giants. Proc Natl Acad Sci USA 113:868-873 
Frew RD, Hutchins DA, Nodder S, Sañudo-Wilhelmy S, Tovar-Sanchez A, Boyd P (2006) Particulate iron dynamics during FeCycle in subantarctic waters SE of New Zealand. Global Biogeochem Cycles 20:GB1S93

*Gove JM, McManus MA, Neuheimer AB, Polovina JJ and others (2016) Near-island biological hotspots in barren ocean basins. Nat Commun 7:10581

Harris G, Nilsson C, Clementson L, Thomas D (1987) The water masses of the east coast of Tasmania: Seasonal and interannual variability and the influence on phytoplankton biomass and productivity. Aust J Mar Freshw Res 38: 569-590

Hutchins D, Wang W, Fisher N (1995) Copepod grazing and the biogeochemical fate of diatom iron. Limnol Oceanogr 40:989-994

Hyrenbach K, Veit R, Weimerskirch H, Metzl N, Hunt G (2007) Community structure across a large-scale ocean productivity gradient: Marine bird assemblages of the Southern Indian Ocean. Deep-Sea Res I 54:1129-1145

Imber M (1999) Diet and feeding ecology of the Royal Albatross Diomedea epomophora-King of the shelf break and inner slope. Emu 99:200-211

Jack L, Wing SR (2011) Individual variability in trophic position and diet of a marine omnivore is linked to kelp bed habitat. Mar Ecol Prog Ser 443:129-139

Jickells TD, An ZS, Anderson KK, Baker AR and others (2005) Global iron connections between desert dust, ocean biogeochemistry, and climate. Science 308:67-71

Karpouzi VS, Watson R, Pauly D (2007) Modelling and mapping resource overlap between seabirds and fisheries on a global scale: a preliminary assessment. Mar Ecol Prog Ser 343:87-99

La Roche J, Boyd PW, McKay RML, Geider RJ (1996) Flavodoxin as an in situ marker for iron stress in phytoplankton. Nature 382:802-805

Lavery TJ, Roudnew B, Gill P, Seymour J and others (2010) Iron defecation by sperm whales stimulates carbon export in the Southern Ocean. Proc R Soc B 277:3527-3531

Lavery TJ, Roudnew B, Seymour J, Mitchell JG, Smetacek V, Nicol S (2014) Whales sustain fisheries: blue whales stimulate primary production in the Southern Ocean. Mar Mamm Sci 30:888-904

Lusseau SM, Wing SR (2006) Importance of local production versus pelagic subsidies in the diet of an isolated population of bottlenose dolphins Tursiops sp. Mar Ecol Prog Ser 321:283-293

Martin J, Gordon R, Fitzwater S (1991) The case for iron. Limnol Oceanogr 36:1793-1802

McCauley DJ, DeSalles PA, Young HS, Dunbar RB, Dirzo R, Mills MM, Micheli F (2012) From wing to wing: the persistence of long ecological interaction chains in lessdisturbed ecosystems. Sci Rep 2:409

McCutchan JH Jr, Lewis WM Jr, Kendall C, McGrath CC (2003) Variation in trophic shift for stable isotope ratios of carbon, nitrogen, and sulfur. Oikos 102:378-390

Editorial responsibility: Rory Wilson,

Swansea, UK
Newsome SD, Tinker MT, Monson DH, Oftedal OT and others (2009) Using stabe isotopes to investigate individual diet specialization in California sea otters (Enhydra lutris nereis). Ecology 90:961-974

Nicol S, Bowie A, Jarman S, Lannuzel D, Meiners K, van der Merwe P (2010) Southern ocean iron fertilization by baleen whales and Antarctic krill. Fish Fish 11:203-209

* Phillips DL, Gregg JW (2001) Uncertainty in source partitioning using stable isotopes. Oecologia 127:171-179

Pietz P (1987) Feeding and nesting ecology of sympatric south polar and brown skuas. Auk 104:617-627

* Post D (2002) Using stable isotopes to estimate trophic position: models, methods, and assumptions. Ecology 83: 703-718

Roman J, McCarthy J (2010) The whale pump: Marine mammals enhance primary productivity in a coastal basin. PLOS ONE 5:e13255

Koman J, Estes J, Morissette L, Smith C and others (2014) Whales as marine ecosystem engineers. Front Ecol Environ 12:377-385

Schmitz O, Raymond P, Estes J, Kurz W and others (2014) Animating the carbon cycle. Ecosystems 17:344-359

* Shatova O, Wing S, Hoffmann L, Gault-Ringold M, Wing L (2016) Seabird guano enhances phytoplankton production in the Southern Ocean. J Exp Mar Biol Ecol 483:74-87

Shealer D (2002) Foraging behaviour and food of seabirds. In: Schreiber E, Burgar J (eds) Biology of marine birds. CRC Press, Boca Raton, FL, p 137-178

* Smith R, Vennell R, Bostock H, Williams M (2013) Interaction of the subtropical front with topography around southern New Zealand. Deep-Sea Res I 76:13-26

* Trites A, Christensen V, Pauly D (1997) Competition between fisheries and marine mammals for prey and primary production in the Pacific Ocean. J Northwest Atl Fish Sci 22:173-187

Walsh R, Hunter K (1992) Influence of phosphorus storage on the uptake of cadmium by the marine alga Macrocystis pyrifera. Limnol Oceanogr 37:1361-1369

*Wing S, Jack L (2012) Resource specialisation among suspension-feeding invertebrates on rock walls in Fiordland, New Zealand, is driven by water column structure and feeding mode. Mar Ecol Prog Ser 452:109-118

Wing SR, McLeod RJ, Clark KL, Frew RD (2008) Plasticity in the diet of two echinoderm species across an ecotone: microbial recycling of forest litter and bottom-up forcing of population structure. Mar Ecol Prog Ser 360: 115-123

Wing SR, Beer NA, Jack L (2012) Resource base of blue cod Parapercis colias subpopulations in marginal fjordic habitats is linked to chemoautotrophic production. Mar Ecol Prog Ser 466:205-214

*Wing SR, Jack L, Shatova O, Leichter JJ, Barr D, Frew RD, Gault-Ringold M (2014) Seabirds and marine mammals redistribute bioavailable iron in the Southern Ocean. Mar Ecol Prog Ser 510:1-13

Submitted: May 3, 2016; Accepted: November 9, 2016 Proofs received from author(s): December 21, 2016 